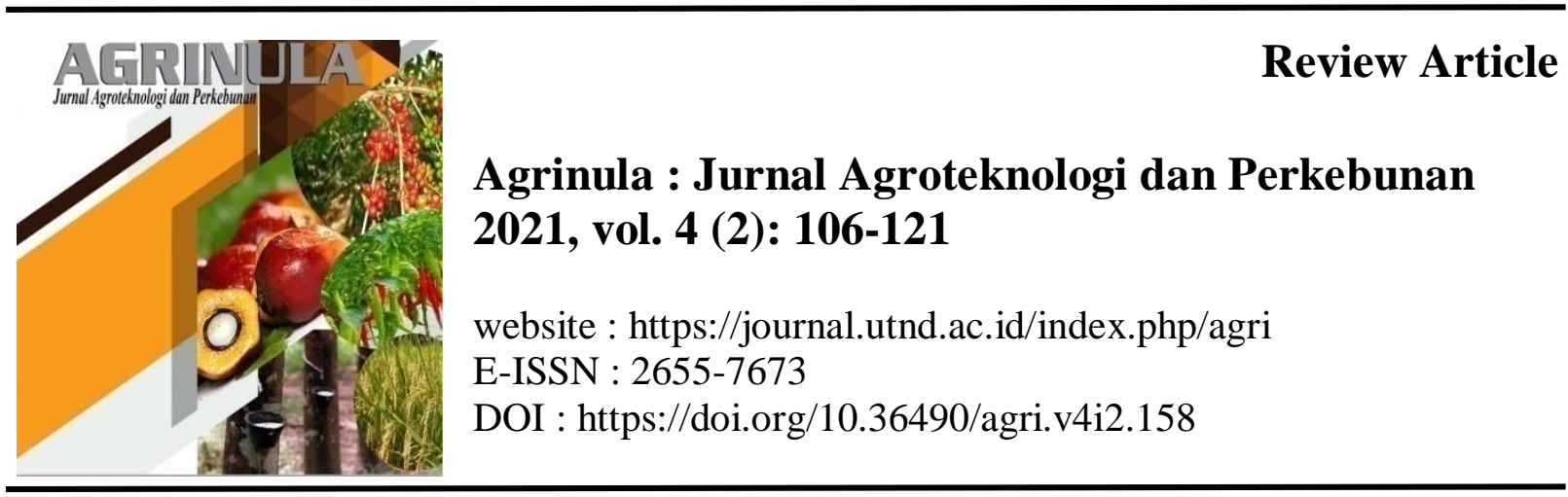

\title{
ROLE OF MICROBES IN PLANT GROWTH AND FOOD PRESERVATION
}

\section{Aqarab Husnain Gondal $^{1 *}$, Qammar Farooq ${ }^{1}$, Irfan Hussain ${ }^{1}$, \& Muhammad Danish Toor ${ }^{2}$}

${ }^{1}$ Institute of Soil and Environmental Sciences, University of Agriculture, Faisalabad 38040, Pakistan.

${ }^{2}$ European University of Lefke, Institute of Graduate Studies and Research, Department of Environmental Sciences Northern Cyprus TR-10 Mersin Turkey.

*Corresponding author: aqarabhusnain944@gmail.com

\begin{tabular}{|c|c|}
\hline Article Information & ABSTRACT \\
\hline $\begin{array}{l}\text { Submitted: } \\
\text { May 05, } 2021 \\
\text { Revised: } \\
\text { June 13, } 2021 \\
\text { Accepted: } \\
\text { June 15, } 2021 \\
\text { Published: } \\
\text { June 17, } 2021\end{array}$ & $\begin{array}{l}\text { - Introduction: Microbes perform better functions for } \\
\text { agricultural production by promoting various direct and } \\
\text { indirect mechanisms in soil and plants. If agricultural } \\
\text { development is to satisfy the needs of an increasing } \\
\text { global population, a deeper understanding of soil } \\
\text { microbiology is needed. Furthermore, microbial biota } \\
\text { such as yeast, bacteria etc., plays a significant role in } \\
\text { food preservation by various mechanisms. } \\
\text { Review results: Despite their pathogenicity, microbes } \\
\text { play a substantial role in dispensing an assortment of } \\
\text { fermented drinks and foods in the food industry and } \\
\text { home. Probiotics, fermented foods and alcoholic } \\
\text { beverages are flattering extra popular due to their health } \\
\text { benefits and flavour. Furthermore, they increase the yield } \\
\text { and growth of plants by improving mineral availability } \\
\text { to the plants and by another mechanism. } \\
\text { Review implementation: This present review also } \\
\text { discusses the various organisms used in the agricultural } \\
\text { processing of beverages and food and the benefits of } \\
\text { using the following microbes in the beverage and food } \\
\text { industry. } \\
\text { Keywords: crop growth and yield; food industry; food } \\
\text { preservation; microbes }\end{array}$ \\
\hline
\end{tabular}




\section{INTRODUCTION}

The soil ecosystem is comprised of inorganic material (iron calcium, oxides, sulfur, nitrates, phosphates, stone particles, and ash), substrates (dead organisms, fallen leaves, dead roots, and rotten wood), organisms (microorganisms, plants, and animals), water and air. It also provides food, fibre, fruit and shelter to all living organisms. The use of agrochemicals in industries and agricultural production leads to contamination of the environment that is a severe problem in the coming days. Furthermore, the world population is increasing by leaps and bounds; thus, already used anthropogenic activities are not sufficient to produce maximum food. Again, agricultural products that are used in the industry become tasteless and poison due to microbial degradation.

Microbes play an essential role in plant growth and development in a variety of pathway. Plant growth-promoting organisms are used to boost agricultural crop growth and yields under natural and stressful conditions. It enhances the growth of crop plants by improving a variety of physiological parameters in response to external stimulants through various mechanisms. Plant growth regulators, the improvement of several metabolites, and the conversion of atmospheric $\left(\mathrm{O}_{2}\right)$ nitrogen into ammonia $\left(\mathrm{NH}_{4}{ }^{+}\right)$are some of the mechanisms that can take part in the growth elevation of plants. It also provides resistance from pathogens through induced systemic resistance and systemic acquired resistance (Kumar \& Verma, 2019).

Microorganisms are well known for their involvement in food spoilage. Still, they also play a beneficial role in the food industry as they are helpful in the preservation of food and dairy products, i.e. fermentation. In the process of fermentation, microorganism are used, and they increase the shelf life of food. Lactic acid bacteria (LAB) are used in several fermentation and preservation process as their metabolic characteristics are unique. For example, milk, meats, cereals, and vegetables (Caplice \& Fitzgerald, 1999). The unique ability of LAB is a production of Bacteriocins. It is an anti-microbial compound, so LAB is used as a preservation agent. In milk fermentation, it is used as a "starter culture", so it produces acid in the fermentation process of milk (Rakhmanova et al., 2018). Microorganisms play a vital role in the growth of plants. They live in the rhizosphere of plants, and it is an interface of plant-microbe where they interact with the plants' roots, and many processes like exchange of materials and signalling process occur (Qiao et al., 2017). There is a strong interaction between plants and microorganisms living in the soil. They are involved in many essential mechanisms for both communities of plants and microbes, e.g. neutral, synergistic or antagonistic mechanisms. Among microorganisms living in the rhizosphere, plant growth-promoting bacteria (PGPB) are most important because they stimulate the growth of plants by several processes, i.e. nitrogen fixation, regulation of soil nutrients availability, suppression of pathogens, and modify the response of plants for biotic and abiotic stresses (Shameer \& Prasad, 2018).

Hence the study of microbes towards agricultural production and food preservation in the industry is essential. Previous studies show that microbes play a crucial role in almost every field of life. The main objectives of this study are (a) to 
highlight the role of microbes in plant growth and development, (b) to demonstrate the role of microbes in food industries.

\section{RESULT REVIEW}

\section{Role of Microbes in Soil Development}

The presence of microorganisms influences the formation and development of soils. During soil formation, microorganisms produce several pores and crevices so that roots of plants can easily penetrate the cracks and production of soil fragmentation is increased. Many factors control the rate of soil development, and microorganisms are an essential factor (Egli et al., 2011). Soil nutrients status is also determined by microbes quality and their identification in the soil (Lombard et al., 2011). For soils' development, microorganisms play a crucial role in improving soil fertility status and overall health.

Bacteria, actinomycetes, fungi, algae, protozoa, and viruses are all forms of soil microorganisms. All organisms have unique traits that distinguish them from one another and define their function in the soil. Importantly, these creatures do not exist in isolation; they interact, and their interactions impact soil production equivalent to or larger than the individuals' behaviour (Berg et al., 2010). Microorganisms are critical to soil creation and soil ecology because they regulate the flux of nutrition to plants (control of the biomass, sulphur, and nitrogen cycles), support nitrogen fixation, and encourage the soil detoxification of inorganic material naturally stirring organic contaminants. In addition, many bacteria exist in symbiotic relationships with plant roots, creating a zone with the high microbial activity known as the rhizosphere (Zhu et al., 2019).

The soil micro, meso, and macro-fauna have a beneficial association. For example, protists, tiny nematodes, rotifers, tardigrades (microfauna) with a body size of fewer than $100 \mathrm{~m}$, springtails, detritivore, and predatory mites, proturans, symphylans (mesofauna) with a body size of between $100 \mathrm{~m}$ and $2 \mathrm{~mm}$, and insects such as ants, carabids, termites, cicadas, and many species The majority of soil activities and significant biogeochemical cycles are thought to be primarily governed by soil microbial populations (FAO, 2017).

Earthworms, Nematodes, Acarina, Collembola, Mollusks, and various pests and grubs feed primarily on decomposing organic materials and life. They're all part of the soil food web, helping to move organic materials from the soil to fungal and bacterial biomass. Soil microbiology is a young field, with just around $1 \%$ of soil microbes described so far (Brown et al., 2000). Fungi and bacteria are heterotrophic organisms that eat the micronutrients (zinc) and minerals released by decaying organic waste. As a result, they're crucial to the nutrient recycling system that keeps soils healthy for plant growth. One kind of soil's microorganism culture differs from another kind of soil's microorganism culture (Bossio et al., 1998).

Microorganisms are present on soil surface and form "bio crust". These bacteria can alter soil chemical and biological features such as crucial nutrient cycling (i.e. nitrogen and carbon), nitrogen and carbon fixation rates in soil, and soil fertility (Rossi 
et al., 2015, Rashid et al., 2016). Soil aggregate stability, bulk density, particle density, water holding capacity, soil organic matter levels, carbon, and nitrogen are all affected by soil microbial activity and density (Veum et al., 2014).

Microbes help form the physical structure of soils by secreting organic chemicals (mostly sugar) that act as "bonding agents" in the soil, glueing soil particles together and forming soil structure. Other soil physical qualities are influenced indirectly by soil microbes; for example, improved soil structure increases soil porosity, leading to more significant air and water penetration. Soil microbes also create extracellular polysaccharides or other cellular waste, which aid in the preservation of soil structure and soil health (Wani et al., 2015). Colica et al., (2014) also found that when microorganisms (Cyanobacteria) released polysaccharides, soil structure improved, and soil hydraulic conductivity decreased. According to Rossi \& De Philippis, (2015) the development of biofilms by cyanobacteria is beneficial in enhancing soil's physical and chemical properties. For instance, soil surface particle adhesion and carbon sequestration in soil.

Important activities microorganisms in soil include: (1) soil organic matter mineralization and nutrient cycling (Miransari, 2011a), (2) soil structure improvement (Egamberdiyeva, 2007), (3) positive interaction with other soil microorganisms (Miransari, 2011b), (4) production of biochemicals like plant hormones and essential enzymes (Compant et al., 2010), and (5) suppression of plant pathogens (Mendes et al., 2011).

Nitrogen is present in our environment, but it is not available for plant use. However, some specific bacteria can capture this atmospheric nitrogen and transfer it into the plant-available form. These microorganisms are known as "nitrogen fixation bacteria". This microbial process is most important for plants and the overall agricultural system because it reduces chemical nitrogen fertilizers dependence. According to estimation, the biological nitrogen fixation process produces nitrogen 200 million tons per annum globally. Soil microorganisms like bacteria have a symbiotic relationship, and these are also known as "rhizobia", including genera Rhizobium, Bradyrhizobium, Mesorhizobium, and Sinorhizobium, with the roots of leguminous crops which generate nodules that are responsible for atmospheric nitrogen fixation by nitrogenase enzyme activity (Graham \& Vance, 2003).

Some other soil functions are also driven by the diverse set of soil microorganisms contributing to functional resilience like decomposition. Moreover, other relevant soil functions are involved in more specific set of soil microorganisms, for example, nitrifiers and bio-control agents. It has been observed that the makeup of the soil organism community can affect numerous activities in the soil ecosystem, including plant variety, decomposition, nutrient retention, and cycling (Semhi et al., 2008). These micro and macro-organisms work together to improve soil quality. Macrofaunal creatures play an essential role in the soil system as colonisers, comminutors, and engineers, and their interactions with microbes are critical for this (Sofo et al., 2020). 
The most effective bio-agent for improving soil health and fertility are the soil microbes.

\section{Role of Microbes in Plant Growth and Yield}

The soil microbial dynamics have a crucial role in determining the soil's ability to create crop yield. They change the $\mathrm{pH}$ of the earth by numerous factors, resulting in the absorption of a variety of macro and micronutrients, particularly zinc (Gondal et al., 2021a; 2021b; 2021c; 2021d). While plant-microbe interactions are an essential aspect in controlling ecosystem functioning, they vary significantly and are influenced by nutrient availability. Plant growth-promoting microorganisms are primarily employed to stimulate plant development via many methods, including nitrogen fixation and plant growth regulation (Ahmad et al., 2008). Around the last two decades, the use of plant growth-promoting microorganisms for sustainable agriculture has increased substantially worldwide. Scientists have found considerable improvements in the growth and production of main agronomic crops due to them (Amara \& Dahdoh, 1995; Hilali et al., 2001; Asghar et al., 2002). Microbes aid in converting phosphorus from an insoluble state to a plant-available form (Istina et al., 2015). The ability of plant-growth promoting bacteria (PGPB) strongly supports to control drought stress in wheat (Kasim et al., 2013). According to Verma et al., (2013) microbes boost nodulation, nutrient absorption, and chickpea yield. Furthermore, it is noticed that many bacterial species have been used for the mineralization of organic contaminants in soil, i.e. bioremediation of soil pollutants (Zaidi et al., 2006). Three types of machines are typically studied and put forward to describe that how microscopic activity can lead to the improvement in plant growth: (a) by manipulating the plant hormonal signalling (Verbon \& Liberman, 2016), (b) by pathogenic microscopic strain outcompeting or repelling (Mendes et al., 2013), (c) by increasing soil-borne nutrients bioavailability (Van Der Heijden et al., 2008).

Bacteria like rhizospheric and the endophytic contributes to promoting plant growth by producing several hormones, inhibiting the pathogens and enhancing the availability of nutrients (Friesen et al., 2011). Some microorganism that is beneficial for plants growth are free-living bacteria (Azotobacter), association forming bacteria with plants (Azospirillum) and bacteria that for symbiosis relationship with legumes and other crop plants (Rhizobium and Bradyrhizobium) (Postgate, 1982). In addition, soil microorganisms help improve soil productivity and the overall ecosystem, so these are being used worldwide to enhance the growth and yield of plants.

Microorganisms require adenosine triphosphate (ATP) 16 molecules during nitrogen fixation to reduce each mole of nitrogen. Microorganisms obtain this energy by the oxidation of organic molecules. In the case of free-living organisms, energy is obtained by other organisms. Photosynthetic organisms like cyanobacteria utilize sugars that is an end product of photosynthesis. Associative or symbiotic $\mathrm{N}$-fixing microorganisms get such compounds from the rhizosphere of host plants (Hubbell \& Kidder, 1998), such as: 
1) Increase in root growth either by root systems extensions like mycorrhizal associations or stimulation of hormones for root growth, root branching, development of root hair or phytostimulation; like indole-3-acetic acid production, involving of enzymes that change ethylene precursors in plants, like 1aminocyclopropane-1-carboxylate deaminase (Hayat et al., 2010).

2) Change in sorption equilibria. This has resulted in a higher net transfer of ions like orthophosphate into the soil solution. Facilitation of organic phosphorus mobility directly or indirectly by microbial turnover (Seeling \& Zasoski, 1993).

3) Metabolic processes induction. these are effective in phosphorus solubilizing and mineralizing directly from the sparingly available soil inorganic and organic phosphorus forms (Richardson et al., 2009).

\section{Role of Microbes in Food Industries}

Microbes play a crucial part in the food industry. They are involved in distributing a wide range of foods, and they are often responsible for food poisoning, which leads to inebriation and illness (Koch, 1990). Microbial contamination of food happens most often during the shipment of foods from the field to the distribution plant and during processing, packaging, transportation, collection, and before use. While most pathogenic or disease-causing bacteria are gramme negative (-ve), food poisoning has been compared to three (3) gramme positive $(+v e)$ rods: Botulinum toxin is a toxin produced by Clostridium botulinum (Srivastava, 2003). They expand quickly and take up less space than traditional crops. Petroleum oil, methanol, ethanol, sugar, molasses, and waste from paper mills are among the low-cost agricultural and industrial waste materials they eat. The secondary advantage is that they help with product recycling, which reduces emissions. They grow a large quantity of fruit. In a 1000 pound yeast growth medium, several tonnes of protein is produced in a single day. This is about 1015 times more than soybeans and 25-50 times more than maize (Hardy, 2002). This is because the cells have a lot of protein. In yeast cells, protein content ranges from 40 to 50 percent; in algae, protein content ranges from 20 to 40 percent.

\section{Role of Microbes in Food Preservation}

Nature uses microorganisms to carry out fermentation processes, and yeasts, moulds, and bacteria have been used to produce bread, vinegar, beer, yoghurt, cheese, and wine and fruit, vegetables, and fermented fish for thousands of years. Fermentation is the earliest methods of food transformation and preservation. This biological process increases the nutritional and organoleptic properties of food while still preserving it. Microbes are used in the fermentation of dairy products and the manufacture of alcoholic beverages. Sour cream, yoghurt, buttermilk, curd, bread, and cheese are some of the most popular dairy products processed by microbes. Soil organisms are also members of many food chains, acting as sources of nutrients for one another, and are often the prominent members of soil biota food chains. 


\section{Use of Microbes in Food Production and Preservation}

Microorganisms are used by nature for the fermentation process. Humanity uses microorganism from thousands of years, including yeasts, moulds, and bacteria, to produce food products like bread, beer, wine, vinegar, yoghurt, cheese, fermented fish, meat, and vegetables. Microbial cultures are used as "meat starter" cultures to produce dried and fermented products, i.e. salami, pepperoni, chorizo and dried ham. Bacteria like lactic bacteria are used in the flavour and colour development of different products. Lactic acid bacteria also play a vital role in converting unstable malic acid (naturally present in the wine) into a stable form. This conversion has resulted in high-quality wine product, and for wine storage, these are beneficial. Some other bacterial strain like Streptococcus, Lactobacillus, Bifidobacterium and Erwinia is used in fermented food and dairy products production. Yoghurt is produced by the presence of Streptococcus thermophilus and Lactobacillus bulgaricus.

Moulds are being used in different food manufacturing, i.e. cheese. For ripening of sausages surface, preservation of products natural qualities and flavours development, moulds are commonly used. Molds are being grown as a source of feed and food too. These are also employed for ingredients production like enzymes, i.e. amylase used in bread making or citric acid for soft drinks. These are considered significant contributors to the ripening of several oriental foods. Like Bothrytiscinerea spp. is involved in grape rotting and wine production. In lactic fermentations, moulds are used that resulted in unique fermented milk known as "viili". Yeasts are involved in the fermentation process like in wine; it produces alcohol.

\section{Post-harvest Damages of Microbes}

When the crops are harvested, it undergoes series of different operations that can cause quantitative and qualitative losses. When the grain and pulses are not thoroughly dried, the chances of mould development by microorganism are higher. Approximately all agricultural products stored over a long time period are widely subjected to a various microorganism that causes food products degradation by rotting or reducing palatability of products by inducing odd taste. Some organisms, i.e. Aspergillus, Penicillium, and Fusarium, can produce mycotoxins on food, making the food unsafe, which is the primary cause of disease and even death in humans as well in animals (Law \& Cooper, 2001). Yeasts that is responsible for food spoilage is divided into four groups:

1) Zygosaccharomyces cause spoilage in honey, dried fruit, jams, and soy sauce. It can tolerate higher concentrations of sugar and salts (Rawat, 2015).

2) Debaryomyces hansenii can grow at greater concentrations of salts (up to $24 \%$ ). Therefore, cured meats, cheeses, and olives in salt brine are spoiled by this one (Mandrell et al., 2005).

3) Some Saccharomyces spp. strains can spoil alcoholic beverages products, i.e. wine spoilage, by causing turbidity, gassiness, and off-flavours in it. However, some species of the same group can grow on the fruits, even on the yoghurt containing fruits, which are heat resistant (Elez-Martinez et al., 2004). 
4) Fermented foods are mainly spoiled by Dekkera/Brettanomyces, i.e. alcoholic beverages and dairy products, including milk. Because they can produce volatile phenolic compounds that cause off-odour and make the flavour unpleasant, it ultimately resulted in massive loss to the winery business (Couto et al., 2005).

\section{In Fruits and Vegetables}

As fruits and vegetables are perishable and contain higher contents of moisture. So these are highly susceptible to spoilage caused by microbes like fungi, bacteria, yeast and moulds. So during their post-harvest period, fungal and bacterial diseases can cause considerable loss (Yahaya \& Mardiyya, 2019; Ch et al., 2021). These pathogens can cause the rotting of items and make them unfit for consumption as they produce mycotoxin (Fatima et al., 2009). Common pathogens involved in post-harvest damage are Alternaria, Fusarium, Penicillium, Aspergillus, Geotrichum, Phytophthora and Botrytis; these are responsible for about $10-30 \%$ yield reduction in a vegetable like a tomato (Etebu et al., 2013). Penicillium expansum is the significant and essential pathogen during a post-harvest period of pear fruit in storage that can cause the blue mould rot. This leads to substantial economic losses during the postharvest period (Amin et al., 2017; Haroon et al., 2020).

\section{In Flowers}

In flowers, the damage is also caused by microorganisms after harvesting, primarily due to interruption of water contents because microorganisms start their growth in the vas solution, so the xylem blockage is faced in the stored flowers stem. Blockage of the branch is mainly caused by a microorganism and some other factors like by production of extracellular polysaccharides and dead cells degradation. Bacteria are also involved in the secretion of pectinases, some toxic compounds and ethylene, accelerating the senescence process. It was also observed that besides reduction in vase life, water relations disruption in the flowers (rose) could cause a problem in flower opening, the flowers are opened improperly, or maybe flowers start to wilt (Jowkar et al., 2012).

\section{In Dairy Products}

Bacteria that cause milk spoilage may be originated on-farm environment or the milking equipment or in the processing plants, transferred from the kit, employees or maybe from the air. When the lactic acid and some other compounds are produced, offflavour is milk is observed, especially when the microorganism's population reach 106 $\mathrm{CFU} / \mathrm{ml}$. Refrigeration is helpful in lactic acid bacteria growth suppression. Still, other psychrophilic bacteria, i.e. Pseudomonas, Alcaligenes, Enterobacter, and some sporeformers, can grow within 25 hours and produce rancid odours (Dogan \& Boor, 2003). The process of pasteurization can kill both psychrophiles and mesophilic bacteria (lactic acid bacteria). However, heat-tolerant species like Alcaligenes, Microbacterium, 
Bacillus and Clostridium can survive and, in the end, cause milk spoilage and in other dairy products (Rawat, 2015).

\section{In Eggs}

Under poor conditions of storage and management, the percentage of moisture in eggshell is increased, making it favourable for the growth of fungal (mould) that cause eggshells spoilage. When the fungal activities are grown on the surface of eggshells, the pore size on the eggshell is increased, and the microbe's entry through the shell becomes easier. Types of spoilage can be characterized by egg colour very often (Erkmen \& Bozoglu, 2016).

\section{Precautions}

Nature uses microorganisms to carry out fermentation processes, and yeasts, moulds, and bacteria have been used to produce bread, vinegar, beer, yoghurt, cheese, and wine and fruit, vegetables, and fermented fish for thousands of years. Fermentation is the earliest methods of food transformation and preservation. This biological process increases the nutritional and organoleptic properties of food while still preserving it. Sour cream, yoghurt, buttermilk, curd, bread, and cheese are some of the most popular dairy products processed by microbes.

Bacteria, moulds, and yeast are the most common microorganisms that cause food spoilage and are widely used in food and food product processing. For the fermentation of dairy products, various bacteria and fungi are used to produce a broad range of cultured milk products. In these cheese-making techniques, bacteria and fungi are also included. Lactic acid bacteria coagulate milk, which can then be used to produce various cheeses such as soft unripened, soft-ripened, semisoft, rugged, and very hard types. Microbes such as Bifidobacterium and Lactobacillus are used in the food industry. For example, alcoholic drinks and other beer products are made by fermenting cereals and grains with various yeast strains.

We can prevent pathogenic infections by volatile organic compounds. Biofumigation is a gaseous treatment; this can be used to get rid of this problem. Different plants that produce volatiles can be used as potential substances for biofumigation (Stelmach-Mardas et al., 2016). To prevent microbial growth in the vase solutions of cut flowers, several compound/chemical like silver nitrate, silver thiosulphate, aluminium sulfate, and sodium hypochlorite are considered beneficial (Liao et al., 2000). Organisms like yeasts, i.e. Pichia guilliermondii, are used to control post-harvest damages like rot in citrus and some other fruits. Like for the post-harvest apple, rot prevention species of Cryptococcus and Acremonium breve are helpful. These are also used to control rot in pear (Schnable et al., 2009). To preserve food and beverages, safe additives that are anti-microbial are added, like acetic, sorbic, and benzoic acids (Choudhary et al., 2017). Some other commonly used preservation agents are following: acetic, lactic, benzoic, and sorbic acid. These are capable of inhibiting fungal and 
bacterial cells outgrowth. Specially sorbic acid is utilized to inhibit bacterial spore's germination and outgrowth (Rawat, 2015).

Crops grains are preserved for a long time after their post-harvest, so these are treated with some pesticides, drying, debranding, irradiation, and other ozone treatment. Chlorine and hypochlorite are also helpful for this purpose (Los \& Timmer, 2018). milk spoilage is controlled by the process of pasteurization or sterilization and milk dehydration. For dairy products, preservation of antimicrobial agents and some generally regarded as safe (GRAS) substances have used that work as food additives, stabilizers and emulsifiers (Verma et al., 2017). Eggs spoilage can be avoided if the conditions are maintained during storage. By washing or applying disinfectants (hypochlorite solution), microbes can be removed from eggs. Eggs pasteurization or use higher or lower temperature treatments would conceal microbially (Erkmen \& Bozoglu, 2016).

\section{Future Opportunites}

Among the most creative technologies, research and industry are increasingly focused on the synthesis of microbial protein (MP) for regulated and intense systems known as "bioreactors." MP has modest needs for arable land, does not compete directly with crop-based food products and uses fertilizer at an efficiency of about $100 \%$. Furthermore, from an economic viewpoint, currently only in specific market segments, such as aquaculture, use of MP in animal feeding is justified. Finally, the European Food Safety Authority must approve innovative MPs before accessing the market. Because of the externalised environmental problems of the existing agri-food production system, the use of microorganisms as food will depend primarily on favourable laws, public acceptability, and lower prices.

\section{CONCLUSION}

Microbes perform better functions for agricultural production by promoting various direct and indirect mechanisms in soil and plants. Bacteria are the best plentiful microbes in the ground, followed by fungi, actinomycetes, soil protozoa and soil algae. A single gramme of soil can contain hundreds of millions to billions of microbes. Therefore, if agricultural development is to satisfy the needs of an increasing global population, a deeper understanding of soil microbiology is needed. Unfortunately, agricultural activities continue to endanger the stable microbe population in many areas rather than encourage the stable microbe population.

Furthermore, food decay and spoilage are caused by microbes. A rotten food product has a foul odour, flavour and texture. Despite their pathogenicity, microbes play a substantial role in dispensing fermented drinks and foods in the food industry and home. Probiotics, fermented foods and alcoholic beverages are flattering extra popular due to their health benefits and flavour. Microbes influence agricultural productivity through a variety of overt and indirect processes in soil and plants. Bacteria, fungi, actinomycetes, plant protozoa, and soil algae are the most abundant bacteria in the 
ground. Bacteria, moulds, and yeast are the most common microorganisms that cause food spoilage and are widely used in food and food product processing. A single gramme of soil can contain hundreds of millions to billions of microbes and thus; can be used for enhancing yield and growth directly and indirectly.

\section{REFERENCES}

Ahmad, F., Ahmad, I., \& Khan, M. S. (2008). Screening of free-living rhizospheric bacteria for their multiple plant growth promoting activities. Microbiological Research, 163(2), 173-181. https://doi.org/10.1016/j.micres.2006.04.001.

Amara, M. A., \& Dahdoh, M. S. A. (1995). Effect of inoculation with plant-growth promoting rhizobacteria, Pgpr on yield and uptake of nutrients by wheat grown on sandy soil. In 5. National Congress on Bio-Agriculture in Relation to Environment, Cairo (Egypt), 20-21 November 1995.

Amin, S. A., Ahmed, A. I., Sidiq, S. A., \& Mahmood, H. A. (2017). Biological control of post-harvest disease of blue mould (Penicillium expansum) of pear fruit by using antagonist microorganisms under laboratory and cold storage conditions. International Journal of Current Research in Biosciences and Plant Biology, 4(1), 20-31. http://dx.doi.org/10.20546/ijcrbp.2017.401.004.

Asghar, H., Zahir, Z., Arshad, M., \& Khaliq, A. (2002). Relationship between in vitro production of auxins by rhizobacteria and their growth-promoting activities in Brassica juncea L. Biology and Fertility of Soils, 35(4), 231-237. https://doi.org/10.1007/s00374-002-0462-8.

Berg, M. P., Kiers, E. T., Driessen, G., Van Der Heijden, M., Kooi, B. W., Kuenen, F., Liefting, M., Verhoef, H. A., \& Ellers, J. (2010). Adapt or disperse: understanding species persistence in a changing world. Global Change Biology, 16(2), 587-598. https://doi.org/10.1111/j.1365-2486.2009.02014.x.

Bossio, D. A., Scow, K. M., Gunapala, N., \& Graham, K. J. (1998). Determinants of soil microbial communities: effects of agricultural management, season, and soil type on phospholipid fatty acid profiles. Microbial ecology, 36(1), 1-12. https://doi.org/10.1007/s002489900087.

Brown, G. G., Barois, I., \& Lavelle, P. (2000). Regulation of soil organic matter dynamics and microbial activityin the drilosphere and the role of interactionswith other edaphic functional domains. European Journal of Soil Biology, 36(3-4), 177-198. https://doi.org/10.1016/S1164-5563(00)01062-1.

Caplice, E., \& Fitzgerald, G. F. (1999). Food fermentations: role of microorganisms in food production and preservation. International Journal of Food Microbiology, 50(1-2), 131-149. https://doi.org/10.1016/S0168-1605(99)00082-3.

Ch, B. I., Gondal, A. H., Zafar, H., Umar, H., Toor, M. D., Zafar, A., Farooq, Q., \& Saeed, S. (2021). A brief correspondence on glyphosate remediation using microbes and mineral sources. Annals of Reviews and Research, 6(4), 555693. http://dx.doi.org/10.19080/ARR.2021.06.555693.

Choudhary, M., Kumar, R., Datta, A., Nehra, V., \& Garg, N. (2017). Bioremediation of heavy metals by microbes. In Bioremediation of salt affected soils: an Indian perspective (pp. 233-255). Springer, Cham. https://doi.org/10.1007/978-3-31948257-6_12.

Colica, G., Li, H., Rossi, F., Li, D., Liu, Y., \& De Philippis, R. (2014). Microbial secreted exopolysaccharides affect the hydrological behavior of induced 
biological soil crusts in desert sandy soils. Soil Biology and Biochemistry, 68, 6270. https://doi.org/10.1016/j.soilbio.2013.09.017.

Compant, S., Clément, C., \& Sessitsch, A. (2010). Plant growth-promoting bacteria in the rhizo-and endosphere of plants: their role, colonization, mechanisms involved and prospects for utilization. Soil Biology and Biochemistry, 42(5), 669-678. https://doi.org/10.1016/j.soilbio.2009.11.024.

Couto, J. A., Neves, F., Campos, F., \& Hogg, T. (2005). Thermal inactivation of the wine spoilage yeasts Dekkera/Brettanomyces. International Journal of Food Microbiology, 104(3), https://doi.org/10.1016/j.ijfoodmicro.2005.03.014.

Dogan, B., \& Boor, K. J. (2003). Genetic diversity and spoilage potentials among Pseudomonas spp. isolated from fluid milk products and dairy processing plants. Applied and Environmental Microbiology, 69(1), 130-138. https://doi.org/10.1128/AEM.69.1.130-138.2003.

Egamberdiyeva, D. (2007). The effect of plant growth promoting bacteria on growth and nutrient uptake of maize in two different soils. Applied Soil Ecology, 36(2-3), 184-189. https://doi.org/10.1016/j.apsoil.2007.02.005.

Egli, M., Wernli, M., Burga, C., Kneisel, C., Mavris, C., Valboa, G., Mirabella, A., Plötze, M., \& Haeberli, W. (2011). Fast but spatially scattered smectite-formation in the proglacial area Morteratsch: An evaluation using GIS. Geoderma, 164(1-2), 11-21. https://doi.org/10.1016/j.geoderma.2011.05.001.

Elez-Martinez, P., Escola-Hernandez, J., Soliva-Fortuny, R. C., \& Martin-Belloso, O. (2004). Inactivation of Saccharomyces cerevisiae suspended in orange juice using high-intensity pulsed electric fields. Journal of Food Protection, 67(11), 25962602. https://doi.org/10.4315/0362-028X-67.11.2596.

Erkmen, O., \& Bozoglu, T. F. (2016). Food Microbiology, principles into practice. John Wiley \& Sons.

Etebu, E., Nwauzoma, A. B., \& Bawo, D. D. S. (2013). Postharvest spoilage of tomato (Lycopersicon esculentum Mill.) and control strategies in Nigeria. Journal of Biology, Agriculture and Healthcare, 3(10), 51-61.

FAO. (2017). Voluntary guidelines for sustainable soil management. Food and Agriculture Organization of the United Nations, Rome, Italy. Available online: http://www.fao.org/documents/card/en/c/5544358d-f11f-4e9f-90efa37c3bf52db7/.

Fatima, N., Batool, H., Sultana, V., Ara, J., \& Ehteshamul-Haque, S. (2009). Prevalence of post-harvest rot of vegetables and fruits in Karachi, Pakistan. Pakistan Journal of Botany, 41(6), 3185-3190.

Friesen, M. L., Porter, S. S., Stark, S. C., von Wettberg, E. J., Sachs, J. L., \& MartinezRomero, E. (2011). Microbially mediated plant functional traits. Annual Review of Ecology, Evolution, and Systematics, 42, 23-46. https://doi.org/10.1146/annurevecolsys-102710-145039.

Gondal, A. H., Zafar, A., Zainab, D., Toor, M. D., Sohail, S., Ameen, S., Ijaz, A. B., Ch, B. I., Hussain, I., Haider, S., Ahmad, I. A., Rehman, B., \& Younas, N. (2021a). A detailed review study of zinc involvement in animal, plant and human nutrition. Indian Journal of Pure \& Applied Biosciences, 9(2), 262-271.

Gondal, A. H., Hussain, I., Ijaz, A. B., Zafar, A., Ch, B. I., Zafar, H., Sohail, M. D., Khan, A. A., Niazi, H., Yousaf, H., Usama, M., Touseef, M., \& Tariq, M. (2021b). Influence of soil $\mathrm{pH}$ and microbes on mineral solubility and plant 
nutrition: A review. International Journal of Agriculture and Biological Sciences, 5(1), 71-81. http://dx.doi.org/10.5281/zenodo.4625364.

Gondal, A. H., Zafar, A., Toor, M. D., Ijaz, A. B., Sohail, S., Ch, B. I., Nawaz, T., Haider, S., Ahmad, I. A., Dua-e-Zainab., Rehman, B., Qasim, M., Shah, M. S., \& Rehman, M. U. (2021c). Alleviation of zinc deficiency from humans through plants by organic sources: A powerful tonic. International Journal of Applied Research, 7(4), 240-243.

Gondal, A. H., Zafar, A., Zainab, D., Toor, M. D., Sohail, S., Ameen, S., Ijaz, A. B., Ch, B. I., Hussain, I., Haider, S., Ahmad, I. A., Rehman, B., \& Younas, N. (2021d). Adaptability of soil pH through innovative microbial approach. Current Research in Agricultural Sciences, 8(2), 71-79.

Graham, P. H., \& Vance, C. P. (2003). Legumes: importance and constraints to greater use. Plant Physiology, 131(3), 872-877. https://doi.org/10.1104/pp.017004.

Hardy, S. (2002). Human microbiology. Taylor \& Francis, London.

Haroon, A., Yaseen, T., Husnain, A., Mehfooz, M., Jarar, M. H., Naveed, U., \& Khalid, F. (2020). Water resources helps in the expansion of mosquitoes colonies. Big Data In Water Resources Engineering (BDWRE), 1(1), 16-21. http://dx.doi.org/10.26480/bdwre.01.2020.16.21.

Hayat, R., Ali, S., Amara, U., Khalid, R., \& Ahmed, I. (2010). Soil beneficial bacteria and their role in plant growth promotion: a review. Annals of Microbiology, 60(4), 579-598. https://doi.org/10.1007/s13213-010-0117-1.

Hilali, A., Prévost, D., Broughton, W. J., \& Antoun, H. (2001). Effets de l'inoculation avec des souches de Rhizobium leguminosarum biovar trifolii sur la croissance du blé dans deux sols du Maroc. Canadian Journal of Microbiology, 47(6), 590-593. https://doi.org/10.1139/w01-068.

Hubbell, D. H., \& Kidder, G. (1998). Biological nitrogen fixation. University of Florida Cooperative Extension Service, Institute of Food and Agriculture Sciences, EDIS.

Istina, I. N., Widiastuti, H., Joy, B., \& Antralina, M. (2015). Phosphate-solubilizing microbe from Saprists peat soil and their potency to enhance oil palm growth and P uptake. Procedia Food Science, 3, 426-435. https://doi.org/10.1016/j.profoo.2015.01.047.

Jowkar, M. M., Kafi, M., Khalighi, A., \& Hasanzadeh, N. (2012). Postharvest physiological and microbial impact of hydroxy quinoline citrate as 'Cherry Brandy'rose vase solution biocide. Annals of Biological Research, 3(5), 22382247.

Kasim, W. A., Osman, M. E., Omar, M. N., Abd El-Daim, I. A., Bejai, S., \& Meijer, J. (2013). Control of drought stress in wheat using plant-growth-promoting bacteria. Journal of Plant Growth Regulation, 32(1), 122-130. https://doi.org/10.1007/s00344-012-9283-7.

Koch, A. L. (1990). Growth and form of the bacterial cell wall. American Scientist, 78(4), 327-341. https://www.jstor.org/stable/29774119?seq=1.

Kumar, A., \& Verma, J. P. (2019). The role of microbes to improve crop productivity and soil health. In Ecological Wisdom Inspired Restoration Engineering (pp. 249265). Springer, Singapore. https://doi.org/10.1007/978-981-13-0149-0_14.

Law, S. E., \& Cooper, S. C. (2001). Air-assisted electrostatic sprays for postharvest control of fruit and vegetable spoilage microorganisms. IEEE Transactions on Industry Applications, 37(6), 1597-1602. https://doi.org/10.1109/28.968166. 
Liao, W., Ho, C. Y., Yan, Y. L., Postlethwait, J., \& Stainier, D. Y. (2000). Hhex and scl function in parallel to regulate early endothelial and blood differentiation in $\begin{array}{lll}\text { zebrafish. } & \text { Development, }\end{array}$ https://doi.org/10.1242/dev.127.20.4303.

Lombard, N., Prestat, E., van Elsas, J. D., \& Simonet, P. (2011). Soil-specific limitations for access and analysis of soil microbial communities by metagenomics. FEMS Microbiology Ecology, 78(1), 31-49. https://doi.org/10.1111/j.1574-6941.2011.01140.x.

Los, B., \& Timmer, M. P. (2018). Measuring bilateral exports of value added: a unified framework (No. w24896). National Bureau of Economic Research.

Mandrell, R. E., Gorski, L., \& Brandl, M. T. (2005). Attachment of microorganisms to fresh produce. In Microbiology of fruits and vegetables (pp. 49-90). CRC Press.

Mendes, R., Garbeva, P., \& Raaijmakers, J. M. (2013). The rhizosphere microbiome: significance of plant beneficial, plant pathogenic, and human pathogenic microorganisms. FEMS Microbiology Reviews, 37(5), 634-663. https://doi.org/10.1111/1574-6976.12028.

Mendes, R., Kruijt, M., de Bruijn, I., Dekkers, E., van der Voort, M., Schneider, J. H., Piceno, Y., DeSantis, T., Andersen, G., Bakker, P, A, H, M., \& Raaijmakers, J. M. (2011). Deciphering the rhizosphere microbiome for disease-suppressive bacteria. Science, 332(6033), 1097-1100. https://doi.org/10.1126/science.1203980.

Miransari, M. (2011a). Soil microbes and plant fertilization. Applied Microbiology and Biotechnology, 92(5), 875-885. https://doi.org/10.1007/s00253-011-3521-y.

Miransari, M. (2011b). Interactions between arbuscular mycorrhizal fungi and soil bacteria. Applied Microbiology and Biotechnology, 89(4), 917-930. https://doi.org/10.1007/s00253-010-3004-6.

Postgate, J. R. (1982). The fundamentals of nitrogen fixation. New York: Cambridge University Press.

Qiao, Q., Wang, F., Zhang, J., Chen, Y., Zhang, C., Liu, G., Zhang, H., Ma, C., \& Zhang, J. (2017). The variation in the rhizosphere microbiome of cotton with soil type, genotype and developmental stage. Scientific Reports, 7, 3940. https://doi.org/10.1038/s41598-017-04213-7.

Rakhmanova, A., Khan, Z. A., \& Shah, K. (2018). A mini review fermentation and preservation: role of lactic acid bacteria. MOJ Food Processing \& Technology, 6(5), 414-417.

Rashid, M. I., Mujawar, L. H., Shahzad, T., Almeelbi, T., Ismail, I. M., \& Oves, M. (2016). Bacteria and fungi can contribute to nutrients bioavailability and aggregate formation in degraded soils. Microbiological Research, 183, 26-41. https://doi.org/10.1016/j.micres.2015.11.007.

Rawat, S. (2015). Food Spoilage: Microorganisms and their prevention. Asian Journal of Plant Science and Research, 5(4), 47-56.

Richardson, A. E., Barea, J. M., McNeill, A. M., \& Prigent-Combaret, C. (2009). Acquisition of phosphorus and nitrogen in the rhizosphere and plant growth promotion by microorganisms. Plant and Soil, 321(1), 305-339. https://doi.org/10.1007/s11104-009-9895-2.

Rossi, F., \& De Philippis, R. (2015). Role of cyanobacterial exopolysaccharides in phototrophic biofilms and in complex microbial mats. Life, 5(2), 1218-1238. https://doi.org/10.3390/life5021218. 
Rossi, F., Olguín, E. J., Diels, L., \& De Philippis, R. (2015). Microbial fixation of $\mathrm{CO}_{2}$ in water bodies and in drylands to combat climate change, soil loss and desertification. New Biotechnology, $\quad 32(1), \quad$ 109-120. https://doi.org/10.1016/j.nbt.2013.12.002.

Schnable, P. S., Ware, D., Fulton, R. S., Stein, J. C., Wei, F., Pasternak, S., et al., (2009). The B73 maize genome: complexity, diversity, and dynamics. Science, 326(5956), 1112-1115. https://doi.org/10.1126/science.1178534.

Seeling, B., \& Zasoski, R. J. (1993). Microbial effects in maintaining organic and inorganic solution phosphorus concentrations in a grassland topsoil. Plant and Soil, 148(2), 277-284. https://doi.org/10.1007/BF00012865.

Semhi, K., Chaudhuri, S., Clauer, N., \& Boeglin, J. L. (2008). Impact of termite activity on soil environment: A perspective from their soluble chemical components. International Journal of Environmental Science \& Technology, 5(4), 431-444. https://doi.org/10.1007/BF03326039.

Shameer, S., \& Prasad, T. N. V. K. V. (2018). Plant growth promoting rhizobacteria for sustainable agricultural practices with special reference to biotic and abiotic stresses. Plant Growth Regulation, 84(3), 603-615. https://doi.org/10.1007/s10725-017-0365-1.

Sofo, A., Mininni, A. N., \& Ricciuti, P. (2020). Soil macrofauna: A key factor for increasing soil fertility and promoting sustainable soil use in fruit orchard agrosystems. Agronomy, 10(4), 456. https://doi.org/10.3390/agronomy10040456.

Srivastava, S. (2003). Understanding bacteria. Springer Science \& Business Media.

Stelmach-Mardas, M., Rodacki, T., Dobrowolska-Iwanek, J., Brzozowska, A., Walkowiak, J., Wojtanowska-Krosniak, A., Zagrodzki, P., Bechthold, A., Mardas, M., \& Boeing, H. (2016). Link between food energy density and body weight changes in obese 229. http://dx.doi.org/10.3390/nu8040229.

Van Der Heijden, M. G. A., Bardgett, R. D., \& Van Straalen, N. M. (2008). The unseen majority: soil microbes as drivers of plant diversity and productivity in terrestrial ecosystems. Ecology Letters, 11(3), 296-310. https://doi.org/10.1111/j.14610248.2007.01139.x.

Verbon, E. H., \& Liberman, L. M. (2016). Beneficial microbes affect endogenous mechanisms controlling root development. Trends in Plant Science, 21(3), 218229. https://doi.org/10.1016/j.tplants.2016.01.013.

Verma, J. P., Yadav, J., Tiwari, K. N., \& Kumar, A. (2013). Effect of indigenous Mesorhizobium spp. and plant growth promoting rhizobacteria on yields and nutrients uptake of chickpea (Cicer arietinum L.) under sustainable agriculture. Ecological Engineering, 51, 282-286. https://doi.org/10.1016/j.ecoleng.2012.12.022.

Verma, S., Marshall, J., Gerbig, C., Rödenbeck, C., \& Totsche, K. U. (2017). The constraint of $\mathrm{CO}_{2}$ measurements made onboard passenger aircraft on surfaceatmosphere fluxes: the impact of transport model errors in vertical mixing. Atmospheric Chemistry and Physics, 17(9), 5665-5675. https://doi.org/10.5194/acp-17-5665-2017.

Veum, K. S., Goyne, K. W., Kremer, R. J., Miles, R. J., \& Sudduth, K. A. (2014). Biological indicators of soil quality and soil organic matter characteristics in an agricultural management continuum. Biogeochemistry, 117(1), 81-99. https://doi.org/10.1007/s10533-013-9868-7. 
Wani, F. S., Ahmad, L., Ali, T., \& Mushtaq, A. (2015). Role of microorganisms in nutrient mobilization and soil health - a review. Journal of Pure and Applied Microbiology, 9(2), 1401-1410.

Yahaya, S. M., \& Mardiyya, A. Y. (2019). Review of post-harvest losses of fruits and vegetables. Biomedical Journal of Scientific \& Technical Research, 13(4), 1019210200. http://dx.doi.org/10.26717/BJSTR.2019.13.002448.

Zaidi, S., Usmani, S., Singh, B. R., \& Musarrat, J. (2006). Significance of Bacillus subtilis strain SJ-101 as a bioinoculant for concurrent plant growth promotion and nickel accumulation in Brassica juncea. Chemosphere, 64(6), 991-997. https://doi.org/10.1016/j.chemosphere.2005.12.057.

Zhu, Y. G., Zhao, Y., Zhu, D., Gillings, M., Penuelas, J., Ok, Y. S., Capon, A., \& Banwart, S. (2019). Soil biota, antimicrobial resistance and planetary health. Environment International, 105059. https://doi.org/10.1016/j.envint.2019.105059. 